\title{
A Rare Cause of Scrotal Mass in a Newborn: Antenatal Intravaginal Testicular Torsion
}

\section{Yenidoğanda Nadir Bir Skrotal Kitle Nedeni: Antenatal Intravajinal Testis Torsiyonu}

\author{
Ahmet Ali Tuncer ${ }^{1}$, Altınay Bayraktaroğlu², Kadir Yümlü ${ }^{3}$, Didem Baskın Embleton¹, Salih Çetinkurşun ${ }^{1}$ \\ ${ }^{1}$ Afyon Kocatepe University Faculty of Medicine, Department of Pediatric Surgery, Afyonkarahisar, Turkiye \\ ${ }^{2}$ Afyonkarahisar State Hospital, Clinic of Pediatric Surgery, Afyonkarahisar, Turkiye \\ ${ }^{3}$ Afyon Kocatepe University Faculty of Medicine, Department of Neonatology, Afyonkarahisar, Turkiye
}

\begin{abstract}
Intravaginal testicular torsion is a very rare pathology in the neonatal period. However, it is the most common type of torsion in puberty. In this article, we present a male patient with testicular hyperemia and a mass in the testis. Ultrasonography revealed intravaginal testicular torsion and absence of testicular blood flow. This paper aims to draw attention to the importance of neonatal examination for the presence of testicular torsion which is a rare pathology in newborns with scrotal colour change or presence of an abnormal mass.
\end{abstract}

Keywords: Testis, Torsion, Newborn, Intravaginal

Öz

Yenidoğan döneminde intravajinal testis torsiyonu çok nadir görülen bir patolojidir. Bu yazıda yenidoğan muayenesinde skrotal hiperemi ve ele gelen kitleyle prezente olan ve ultrasonografik incelemede testiste kan akımın izlenmediği antenatal intravajinal testis torsiyonlu erkek hasta güncel literatür eşliğinde sunulacaktır. Bu makale yenidoğan muayenesinin önemine dikkat çekmek ve yenidoğanda skrotal renk değişikliği veya kitle imajı veren durumlarda nadir bir patoloji olan testis torsiyonunu hatırlatmak amacıyla yazılmıştır.

Anahtar Kelimeler: Testis, Torsiyon, Yenidoğan, İntravajinal

\section{Introduction}

Testicular torsion occurs most commonly in newborn and puberty periods. Newborn testicular torsion frequency is $6.1 / 100000$ (1). Extravaginal torsion is frequently observed in undescended testicle cases and newborns while 95\% of the testicular torsions are seen during puberty except newborn are in the form of intravaginal torsion. Few cases of intravaginal torsion in the neonatal period have been reported in the literature $(2,3)$. In this paper, we present a case of intravaginal testicular torsion in puberty. This can be explained by the fact that intravaginal torsion is characterized by congenital anatomical abnormalities such as a high attachment of the tunica vaginalis to the spermatic cord and an excessive laxity of gubernaculum testis. These events are named as "bell clapper deformity". Intravaginal torsion is caused by the testis twisting within the tunica vaginalis. A child with an antenatal testicular torsion, which is a rare pathology, is presented in this article.

\section{Case Presentation}

A 22-year-old mother gave birth to her second healthy child $(3370 \mathrm{~g})$ in the 38 weeks of her pregnancy. In the routine neonatal examination of the baby, right testicular stiffness and size increase were determined and pediatric surgeon consultation was requested. During physical examination, the left testis was normally palpated but hyperemia was observed in the right hemiscrotum skin and the size increase and stiffness were observed according to the testis symmetry. Blood flow was not observed in the right testicular parenchyma as a result of torsion. Colour Doppler ultrasonography performed with the preliminary diagnosis of testicular torsion showed that the

Correspondence: Ahmet Ali Tuncer MD, Afyon Kocatepe University Faculty of Medicine, Department of Pediatric Surgery, Afyonkarahisar, Turkiye Phone: +90 5059489371 E-mail: drtaali@yahoo.comＯRCID-ID: orcid.org/0000-0002-2750-7317

Received: 08.02.2017 Accepted: 06.03.2017

Cite this article as: Tuncer AA, Bayraktaroğlu A, Yümlü K, Baskın Embleton D, Çetinkurşun S. A Rare Cause of Scrotal Mass in a Newborn: Antenatal Intravaginal Testicular Torsion. J Urol Surg 2018;5(1):44-46.

๑Copyright 2018 by the Association of Urological Surgery / Journal of Urological Surgery published by Galenos Publishing House. 
right testis was heterogeneous in appearance and its size was significantly increased compared with the left testis (Figure 1). The patient was urgently operated. The operation started with the right inguinal transverse skin incision. Right intravaginal torsion and testicular gangrene were observed during the exploration (Figure 2). After detorsion, it was waited for about 15 minutes and parenchymal incisions were made on the testis. However, right orchiectomy was performed because there was no blood supply and the colour was still dark. Necrotic testis tissue was observed. The patient was discharged on the second postoperative day and he was followed without complication in the forth-postoperative month.

Written informed consent was obtained from patient parents who participated in this study.

\section{Discussion}

Testicular torsion is the most important occurrence among acute scrotum pathologies and it is a condition requiring immediate intervention (4). The survival of the gonad in testicular torsion depends on two important factors: the grade and duration of the torsion. Experimental animal studies have reported that 90-degree testicular torsion did not affect the circulation, and 180-, 360-, and 720-degree torsions lead to permanent loss of the testis within 3-4 days, 12-24 hours, and 2 hours, respectively (5). $92 \%$ of newborn testicular torsions are extravaginal and $8 \%$

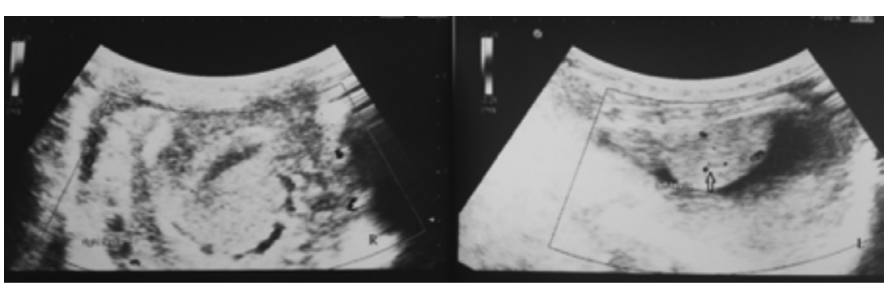

Figure 1. Colour Doppler ultrasonography revealed that the testis was heterogeneous in appearance and its size was significantly increased compared to the symmetry. Unlike the left testis, no blood flow was observed in the right testis (arrow shows the vascular coding in right testis)

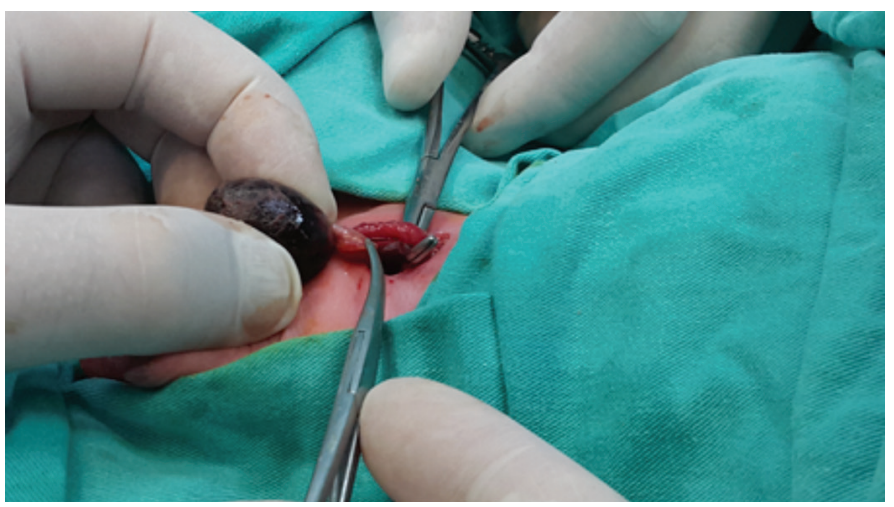

Figure 2. Peroperative apperence of the right testis. Intravaginal testicular torsion and necrosis of testicular tissue are observed are intravaginal. Torsions in this age group account for 10\% of all testicular torsions (6). It has been reported that $48 \%$ of newborn torsions were in the left side, $44 \%$ in the right side, and $8 \%$ were bilateral (7). Intravaginal presentation of the torsion in the right side reported in this paper is a rare condition for this age group. Emergency surgical intervention in prenatal testicular torsion remains controversial. It has been reported that, the testis was preserved in approximately $22-33 \%$ of patients with postnatal testicular torsion with the help of the immediate surgical intervention; however, testes were not preserved in patients who had prenatal testicular torsion and who were urgently operated in the neonatal period $(8,9)$. Nandi and Murphy (7) have indicated that the salvage rate was low in their experience with neonatal torsion. For instance, it has been found in a review of 18 case series of neonatal testicular torsion including 268 patients that the salvage rate was approximately 9\% (7). Scrotal-inguinal hernia, testicular tumour, epididymoorchitis, torsion of the appendix testis, and testicular epididymal torsion should be considered in the differential diagnosis in the acute phase (10). In our case study, tumour markers such as alpha-fetoprotein and beta-human chorionic gonadotropin were examined but no significant difference was found in this age group. However, it should not be forgotten that such markers may normally be found to be high in the newborn period and must be checked for a while. Whether or not to fix the contralateral testis should be discussed during the surgical intervention with ipsilateral testis (9). It is also recommended that the fixation of the contralateral testis can be performed in the second session (3). In our study, no fixation was performed in the contralateral testis in the same session. Instead, fixation will be performed after the age of one in another operation in order to protect the contralateral testis from complications such as infections. In conclusion, in the case of scrotal colour change and presence of an abnormal mass, testicular torsion should be kept in mind and surgical treatment should be provided.

\section{Ethics}

Informed Consent: Written informed consent was obtained from patient parents who participated in this study.

Peer-review: Externally peer-reviewed.

\section{Authorship Contributions}

Surgical and Medical Practices: A.A.T., K.Y., A.B., Concept: A.A.T., A.B., Design: A.A.T., A.B., Data Collection or Processing: A.A.T., K.Y., Analysis or Interpretation: S.Ç., A.A.T., D.B.E., Literature Search: A.A.T., K.Y., A.B., D.B.E., Writing: A.A.T., A.B.

Conflict of Interest: No conflict of interest was declared by the authors.

Financial Disclosure: The authors declared that this study has received no financial support. 


\section{References}

1. John CM, Kooner G, Mathew DE, Ahmed S, Kenny SE. Neonatal testicular torsion- a lost cause? Acta Paediatr 2008;97:502-504.

2. Van Glabeke E, Philippe-Chomette $\mathrm{P}$, Gall O, Oro H, Larroquet M, Audry G. Spermatic cord torsion in the newborn: role of surgical exploration. Arch Pediatr 2000;7:1072-1076.

3. Bordin G, Parolini F, Morandi A, Farris G, Leva E, Torricelli M. Intravaginal testicular torsion in newborns. To fix or not to fix the contralateral testis? Pediatr Med Chir 2013;35:225-227.

4. Al-Salem AH. Intrauterine testicular torsion: a surgical emergency. J Pediatr Surg 2007;42:1887-1891.

5. Sondra LP Jr, Lapides J. Experimental torsion of the spermatic cord. Surg Forum 1961;12:502-504.
6. Das $\mathrm{S}$, Singer A. Controversies of perinatal torsion of the spermatic cord: a review, survey and recommendations. J Urol 1990;143:231-233.

7. Nandi B, Murphy FL. Neonatal testicular torsion: a systematic literature review. Pediatr Surg Int 2011;27:1037-1040.

8. Kaye JD, Levitt SB, Friedman SC, Franco L, Gitlin J, Palmer LS. Neonatal torsion: a 14- year experience and proposed algorithm for management. J Urol 2008:179:2377-2383.

9. Djahangirian 0 , Ouimet A, Saint-Vil D. Timing and surgical management of neonatal testicular torsions. J Pediatr Surg 2010;45:1012-1015.

10. Shipp TD, Benacerraf BR. Scrotal inguinal hernia in a fetus: sonographic diagnosis. Am J Roentgenol 1995;165:1494-1495. 